Chirurgia (2019) 114: 162-166

No. 2, March - April

Copyright $\odot$ Celsius

http://dx.doi.org/10.21614/chirurgia.114.2.162

\title{
"Liquid Biopsy" - Is it a Feasible Option in Colorectal Cancer?
}

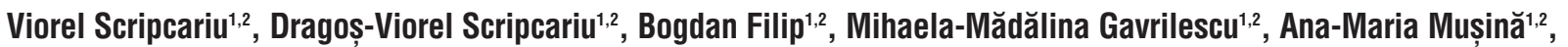 \\ Constantin Volovăț ${ }^{1}$
}

'Faculty of Medicine, "Grigore T Popa" University of Medicine and Pharmacy, Iași, Romania

${ }^{2} 1^{\text {st }}$ Surgical Oncology Unit, Regional Institute of Oncology, Iași, Romania

Corresponding author:

Dragos-Viorel Scripcar, MD

"Grigore T Popa" University of Medicine and Pharmacy

16 Universității street, lași, Romania

E-mail: dscripcariu@gmail.com

\section{Rezumat}

"Biopsia lichidă" - o optiune fezabilă în cancerul colorectal?

Este important pentru chirurg să țină pasul cu noutățile atât din, cât şi din afara sferei lor de activitate. Pe măsură ce medicina evoluează, apar noi tehnici, iar oncologia este unul dintre principalii beneficiari ai lor. "Biopsia lichidă" reprezintă unul dintre cele mai recente domenii de interes în oncologie, deoarece poate oferi detalii importante privind caracteristicile tumorii primare şi ale metastazelor sale. Celulele maligne se află într-o dinamică continuă, ceea ce face ca biopsia inițială, din momentul diagnosticului, dar şi evaluarea piesei anatomopatologice să fie insuficiente în evoluția târzie a bolii, când pot apărea recidive sau metastaze. Faptul că furnizorul de servicii medicale este capabil să găsească informații suplimentare despre tumoră la un moment dat prin evaluarea unei probe de sânge pentru a obține o "biopsie lichidă" este de cea mai mare importanță şi oferă date multiple potențial utilizabile. Există trei modalități de obtinere a unui material biologic care poate fi folosit ca "biopsie lichidă": evaluarea celulelor tumorale circulante, a ADN-ului tumoral circulant şi a exosomilor. Entitatea cea mai intens studiată este aceea a celulelor tumorale circulante, cu aplicații diferite, dintre care cea mai importantă, în prezent, este valoarea prognostică, aceasta având implicații importante, nu numai în cancerul de sân şi prostată, dar şi în cancerul colorectal. Deşi chirurgia nu va fi înlocuită de alte tratamente atunci când vine vorba de o abordare curativă a cancerului rectal, este important pentru chirurg să cunoască informații despre domenii complementare, unul din acestea fiind al "biopsiei lichide". 
Cuvinte cheie: cancer colorectal, biopsie lichidă, celule tumorale circulante, ADN tumoral circulant, exosomi

\section{Abstract}

It is important for surgeons to keep up with improvements both in and outside their field. As medicine evolves, new techniques appear, and oncology is one of the main beneficiaries. "Liquid biopsy" is one of the most recent domains of interest in oncology, as it may provide important details regarding the characteristics of the main tumor and its metastases. Malignant cells are in a continuous dynamic, which makes the initial diagnostic biopsy and the pathological specimen evaluation insufficient in the late evolution of the disease, when relapse or metastases may appear. The fact that the healthcare provider is able to find out additional information about the tumor at a given time, by evaluating a blood sample to obtain a "liquid biopsy" is of utmost importance and gives multiple potentially usable data. There are three means of obtaining biological material that may be used as "liquid biopsy": evaluation of circulating tumor cells, circulating tumor DNA and exosomes. The most intensely studied entity is that of circulating tumor cells, with different applications, amongst which the most important, at present time, is the prognostic value that has important demonstrated implications, not only in breast and prostate cancer, but also in colorectal cancer. Although surgery will, most certainly, not be replaced by other treatments when aiming for a curative approach to rectal cancer, it is important for the surgeon to know information about complementary fields, one of which is comprised by "liquid biopsy".

Key words: colorectal cancer, liquid biopsy, circulating tumor cells, circulating tumor DNA, exosomes

As medicine evolves, the approach to colorectal cancer becomes more and more based on the multidisciplinary team. One of the emerging topics in oncology is about "liquid biopsy", that shows more and more applications and proves to be useful in multiple types of cancer.

Tumors have an important feature that hinders the efficacy of radiotherapy, chemotherapy or targeted therapy, which is genetic heterogeneity (1). Thus, the more information clinicians can get about the tumor, the better and more targeted the treatment will be.

On the other hand, one of the most important prognostic factors in colorectal cancer and the main decision factor that guides chemotherapy is the presence of metastatic disease $(2,3)$. This issue may appear at the initial presentation, after neo-adjuvant treatment (when applicable), or during evolution after surgery.

These are just two of the reasons why the biopsy and the surgical specimen in colorectal cancer are slowly becoming insufficient if we are aiming for an efficient, tailored approach for each patient. In the last two decades, the detection of circulating tumor cells (CTCs) in the peripheral blood flow of the patient has shown to provide important information about the main tumor or its metastases. Because of the apparition of apoptosis of said CTCs, intracellular components are released into the bloodstream, constituting circulating tumor materials: circulating tumor DNA (ctDNA) and exosomes (4). The aforementioned three entities constitute the sources for "liquid biopsy" in cancer and may become important biomarkers for the prognostic and monitorization of neoplastic disease.

CTCs are cells released in the bloodstream from the main tumor. The first documented mention of this entity is in 1869 , by Thomas Ashworth, a pathologist from Melbourne, Australia, who identified multiple atypical cells 
in a post-mortem blood sample from a patient dying of cancer, classifying them as tumor cells that may have been held accountable for multiple tumors disseminated throughout the patient's body (5). However, this subject was not approached until in the 1970's, when it became increasingly popular within the research community, with constantly growing numbers of articles approaching the issue of CTCs (6).

In order to become circulant, tumor cells have to undergo several phenotypic changes, known as the epithelial-mesenchymal transition, through which cells are enabled to detach from and migrate through the basal membrane, thus having the possibility to be released into the blood-flow and be carried to secondary sites and metastasize. These cells may circulate single or in homogenous or heterogenous clusters, with increased chances of "survival" and reaching the target organs (7).

CTCs are rare even in the blood of patients with metastatic disease and are hard to find in a background of blood cells (8); it has been demonstrated that there is approximately one CTC to every $10^{6}-10^{7}$ circulating mononuclear cells (9), although these numbers may vary in accordance to the stage of the neoplastic disease. These aspects lead us to realize the difficulty of isolating CTCs in the patient's peripheral blood; on the one hand, it is hard to identify CTCs due to the low number of such cells in circulation and on the other hand, it is difficult to separate these cells from other circulating blood cells.

Thus, different strategies have been imagined in order to identify CTCs, but all strategies have in common two targets: isolation and detection. Isolation, or enrichment techniques are based upon two approaches: selection by immunologic profile - expression of cell surface proteins such as EpCAM (epithelial cell adhesion molecule), or by morphological characteristics density, size, electric charge. Isolation usually leads to obtaining a solution that contains a combination of CTCs and leukocytes, requiring further processing in order to select the targeted cells: identification, or detection means immunohistochemistry or PCR, RT-PCR (10).
There are many techniques to identify circulating tumor cells; however, the only FDA-certified and the one used to obtain most of the clinical data at present time in colorectal cancer is CellSearch (Janssen Diagnostics) (10), which consists of an affinitybased assessment of $7.5 \mathrm{ml}$ of blood.

There are multiple applications of CTCs in neoplasia in general and in colorectal cancer in particular, as these cells have been more intensively studied in breast cancer, followed by prostate and colorectal cancer (11). The utility of examining CTCs in colorectal cancer patients can be seen from the following points of view(12):

1. as a screening instrument;

2. for diagnostics;

3. as predictive factors for orienting the treatment;

4. as prognostic factors;

5. for guiding and assessing the treatment;

6. as a follow-up tool.

Bearing in mind the above-mentioned low number of CTCs, the utility of evaluating these cells as a screening instrument is yet to be made possible by the availability of instruments for in vivo evaluation (such as CellCollector) (12).

The utility as a diagnostic tool is, as well, to be demonstrated; as aforementioned, by providing important information about the main tumor or its metastases, CTCs may be considered an important companion for a complete diagnostic of the cancer and may be used as a tool of guiding anti-cancer therapies (13). Thus, prognosis of response to treatment may be one additional application of CTCs; it was to date studied in breast cancer, through a phase III clinical trial - the SWOG S0500 trial (14), that evaluated the number of CTCs before, during and after chemotherapy, but was only able to conclude that a large cellcount at the beginning and during chemotherapy is associated with worse survival, with no significant impact on response to chemotherapy. This application would be of great utility for rectal cancer in prediction of response to neoadjuvant treatment or even prediction for the appearance of metastatic disease during or after neoadjuvant treatment. No studies of this 
kind are, to date, present in literature.

The most important application and the only validated one through studies is the prognostic value of CTCs. As above-mentioned, clinical studies in breast cancer set a cutoff value of 5 CTCs in $7.5 \mathrm{ml}$ of peripheral blood of the newlydiagnosed patient as a predictive factor for impaired disease-free survival and overall survival (15). In addition, the $8^{\text {th }}$ edition of the TNM Classification includes the presence of CTCs in the patient's blood in breast cancer as a separate, M0(i+) staging, with possible impact on therapeutic approach (16). This aspect has been studied in colorectal cancer as well, studies setting a cutoff value of 3 CTCs per $7.5 \mathrm{ml}$ of blood as a negative prognostic factor for the patient's survival (17).

Another significant element in the discussion about "liquid biopsy" is ctDNA, which may come from apoptotic or necrotic tumor cells, or may be released into circulation by living tumor cells $(18,19)$.

In cancer patients, the study of ctDNA may have several utilities, such as detection of residual disease after radical surgery as a negative prognostic factor, monitorization of tumor burden - increases in ctDNA may mean disease progression, monitorization of appearance of tumor molecular resistance - guiding therapy in certain patients, or even early detection of certain tumors (20).

Last but not least, exosomes are considered important biomarkers for tumor burden and metastasis and they are abundant in peripheral blood of patients. The study of exosomes is particularly interesting for the oncologist as they are stable carriers of genetic material and proteins from their cell of origin (20).

In conclusion, we see that in a world with constant evolution of the approach to neoplasia, multidisciplinarity is of utmost importance and it is useful for the general surgeon to be up-todate with concepts that may, in the near future, change the way we treat cancer. Although in a very early stage of its existence and in high need of validation, "liquid biopsy" may represent in the future a useful tool of diagnosis, prognosis and follow-up in colorectal cancer. The constantly increasing number of articles on this topic found in literature endorses this idea; in addition, the lower invasiveness of the procedure may represent one more argument for the rise if this technique.

At the time being, surgery is in no danger of becoming futile in colorectal cancer; we must understand the importance of a tailored approach to each cancer patient and the significant advances in medicine that make the work of the multidisciplinary team more and more efficient.

\section{Conflict of Interest}

The authors declare no conflicts of interests.

\section{References}

1. Tsimberidou AM, Iskander NG, Hong DS, Wheler JJ, Falchook GS, Fu S, et al. Personalized medicine in a phase I clinical trials program: the MD Anderson Cancer Center initiative. Clin Cancer Res. 2012;18(22):6373-83.

2. Glynne-Jones R, Wyrwicz L, Tiret E, Brown G, Rodel C, Cervantes A, et al. Rectal cancer: ESMO Clinical Practice Guidelines for diagnosis, treatment and follow-up. Ann Oncol. 2017;28(suppl_4): iv22-iv40.

3. NCCN. NCCN Guidelines Version 1.2018 - Rectal Cancer 2018. Available from: https://www.nccn.org/professionals/physician_gls/pdf/rectal.pdf.

4. Cristofanilli M, Budd GT, Ellis MJ, Stopeck A, Matera J, Miller MC, et al. Circulating tumor cells, disease progression, and survival in metastatic breast cancer. N Engl J Med. 2004;351(8):781-91.

5. Ashworth TR. A case of cancer in which cells similar to those in the tumours were seen in the blood after death. Aus Med J 1869;14:146-9.

6. Datar RH, Ao Z, Cote RJ. Significance of Studying Circulating Tumor Cells. In: Cote RJ, Datar RH, editors. Circulating Tumor Cells - Advances in Basic Science and Clinical Applications. New York: Springer; 2016.

7. Kalluri R, Weinberg RA. The basics of epithelial-mesenchymal transition. J Clin Invest. 2009;119(6):1420-8.

8. Miller MC, Doyle GV, Terstappen LW. Significance of Circulating Tumor Cells Detected by the CellSearch System in Patients with Metastatic Breast Colorectal and Prostate Cancer. J Oncol. 2010; 2010:617421.

9. Ignatiadis M, Lee M, Jeffrey SS. Circulating Tumor Cells and Circulating Tumor DNA: Challenges and Opportunities on the Path to Clinical Utility. Clin Cancer Res. 2015;21(21):4786-800.

10. Sun YF, Yang XR, Zhou J, Qiu SJ, Fan J, Xu Y. Circulating tumor cells: advances in detection methods, biological issues, and clinical relevance. J Cancer Res Clin Oncol. 2011;137(8):1151-73.

11. Shih-Min A. Huang MRL. CTCs for Biomarker and Companion Diagnostic Development. In: Richard J. Cote RHD, editor. Circulating Tumor Cells - Advances in Basic Science and Clinical Applications. New York: Springer; 2016.

12. Scripcariu DV, Lupascu CD. Circulating tumor cells in rectal cancer patients - a review of the literature. Rev Med Chir Soc Med Nat. 2018;122(1):87-95.

13. Punnoose EA, Lackner MR. Challenges and opportunities in the use of CTCs for companion diagnostic development. Recent Results Cancer Res. 2012;195:241-53. 
14. Smerage JB, Barlow WE, Hortobagyi GN, Winer EP, Leyland-Jones $B$, Srkalovic G, et al. Circulating tumor cells and response to chemotherapy in metastatic breast cancer: SWOG S0500. J Clin Oncol. 2014;32(31):3483-9.

15. Ram H. Datar ZA, and Richard J. Cote. Significance of Studying Circulating Tumor Cells. In: Richard J. Cote RHD, editor. Circulating Tumor Cells - Advances in Basic Science and Clinical Applications. New York: Springer; 2016.

16. Jessup JM, Goldberg R, Asare EA. Colon and rectum. In: Amin MB, editor. AJCC Cancer Staging Manual (8th edition). Chicago: Springer; 2017. p. 251-74.

17. Cohen SJ, Punt CJ, Iannotti N, Saidman BH, Sabbath KD, Gabrail NY, et al. Prognostic significance of circulating tumor cells in patients with metastatic colorectal cancer. Ann Oncol. 2009;20(7): 1223-9.

18. Jahr S, Hentze H, Englisch S, Hardt D, Fackelmayer FO, Hesch RD, et al. DNA fragments in the blood plasma of cancer patients: quantitations and evidence for their origin from apoptotic and necrotic cells. Cancer Res. 2001;61(4):1659-65.

19. Stroun M, Lyautey J, Lederrey C, Mulcahy HE, Anker P. Alu repeat sequences are present in increased proportions compared to a unique gene in plasma/serum DNA: evidence for a preferential release from viable cells? Ann N Y Acad Sci. 2001;945:258-64.

20. Toss A, Cristofanilli M. Blood-Based Diagnostics in Solid Tumors: An Overview. In: Cristofanilli M, editor. Liquid Biopsies in Solid Tumors. Chicago: Springer; 2017. 